Table 1. Enfeot of Pretreatment on Mortality of Wheat Seedrings AFTER FREEZING

\begin{tabular}{|c|ccc|}
\hline Pretreatment & \multicolumn{3}{|c|}{ Mortality } \\
$\begin{array}{c}\text { Oxygen (\%) } \\
\begin{array}{c}\text { Temperature } \\
\left({ }^{\circ} \mathrm{C}\right)\end{array}\end{array}$ & $0-1$ & $2-3$ & 21 \\
0.0 & & & \\
$12-15$ & $35 \cdot 1^{*}$ & 24.1 & 13.2 \\
& 33.0 & 46.2 & 60.7 \\
\hline Difference for signifleance $P=0.05$ & 16.0 \\
0.01 & 22.0
\end{tabular}

* Transformed value $\left(P=\sin ^{2} \theta\right)$ of percentage mortality, 3 weeks after

Reduction of oxygen supply had some protective effect, but was also inhibitory to the normal process of lowtemperature hardening. The beneficial result was similar in magnitude to treatments with hydrocyanic acid, narcotics and reduced moisture supply, all of which were capable of bringing about hardening, but not so effectively as did low temperature. These results are in accord with findings of other workers ${ }^{2}$ and may best be attributed to the influence of reduced growth rate, which is common to all treatments. In no case, however, has an effect of the magnitude observed by Siegel et al. been reported.

It is suggested that a likely explanation of their results is that treated plants failed to freeze. In short-term experiments super-cooling is readily achieved and, in fact, usually has to be guarded against by artificial inoculation. Differences in the moisture content of the atmosphere in which plants were frozen could well contribute to differences in behaviour in this regard.

Experiments reported here were carricd out with facilities provided by the University of Sydney.

Agricultural Research Station,

Department of Agriculture,

Tamworth, New South Wales.

I Siegel, S. M., Halpern, L. A., Guimarro, C., Renwick, G., and Davis, G., Nature, 197,329 (1963).

2 Levitt, J., Frost Killing and Hardiness of Plants. A Critical Review (Burgess Pub. Co. : Minneapolis, Minn., 1945).

\section{Polysiphonia urceolata in Axenic Culture}

EFForTs to obtain axenic cultures of red algae hitherto have been successful only with unicellular species ${ }^{1,2}$ or multicellular species with monosiphonous thalli $i^{3,4}$.

Among the unialgal cultures maintained in this laboratory there are species with more complicated structures such as Ceramium strictum, Lomentaria clavellosa and Lolysiphonia urceolata. Small pieces of these species were treated with penicillin in a solution containing 3,000 r.U. $/ \mathrm{ml}$. After $24 \mathrm{~h}$ the species were placed on agar plates with only $2,000 \mathrm{r} .0 . / \mathrm{ml}$. for 10 days. The pieces of Lomentaria and Ceramium had then lost their colour, whereas Polysiphonia appeared alive. The pieces of this alga were then transferred to agar plates containing nutrient medium $A S P$ 6F' with $5 \mathrm{~g}$ ion-agar, $5 \mathrm{~g}$ glucose, $1 \mathrm{~g}$ asparagine and $0.5 \mathrm{~g}$ ' $N$-Z -case' (an enzyme-hydrolysed casein : Sheffield Chemical), per litre ${ }^{5}$. Most pieces were overgrown by bacteria or yeast in a few days, but around three pieces no infections could be observed even after 14 days. These small branches were then transferred to flasks containing $25 \mathrm{ml}$. of the artificial seawater $A S P 6 F$, where they grew out. Later, small pieces from these cultures were tested for purity, and in December 1962 it was possible to establish that Polysiphonia urceolata had been obtained in axenic culture.

As other multicellular red algae had turned out to be more or less vitamin-heterotrophic, the requirement for growth substances was investigated. It was difficult to obtain a suitable form of inoculum for experiments, as Polysiphonia grows with only slightly ramified branches and does not form any sort of spores in culture. Tips of branches were used as inocula, and it was found to be necessary to use branches with at least two or three lateral branches, if the alga were to grow out in all flasks of a series.

The alga could then be tested for possible vitamin requirements. In order to produce as good a response as possible, the alga was starved for vitamins through cultivation in vitamin-free $A S P 6 F^{\prime}$ and transferred into a new solution every week. After four weeks an experiment was performed in the following series: $(a)$ with no vitamins ; (b) with the complete vitamin solution of $A S P 6 F ;(c)$ with $\mathrm{B}_{12}$, riboflavin, pyridoxamine and folic acid; $(d)$ with the remaining 11 substances of the vitamin solution. Growth was very variable within the series, because too small inocula had been used in this experiment; but in series $(a)$ and $(d)$ no growth at all occurred. The vitamin demand was absolute as the vitamin-starved alga died after cultivation in a vitamin-free solution for 8 weeks. Polysiphonia is thus vitamin-heterotrophic and the necessary growth substance or substances were among vitamin $\mathbf{B}_{12}$, riboflavin, pyridoxamine and folic acid. As the earlier examined red algae, Goniotrichum elegans ${ }^{3}$ and Erythrotrichia carnea ${ }^{6}$, were $\mathrm{B}_{12}$-heterotrophic, this compound might be suspected to be the active substance.

In the next experiment, $\mathrm{B}_{12}$ was tested alone or combined with other vitamins. As Table 1 shows, $\mathbf{B}_{12}$ was necessary for growth of Polysiphonia.

Table 1. GRowTH of Polysiphonia urceolata with VITamn $\mathrm{B}_{12}$ (= CyanoCOBALAMIN) ALONE OR IN COMBINATION WITH VARIOUS OTHER VITAMINS.
INCUBATION TIME, 36 DAYS. INOCELA STARVED FOR 28 DAYS

$\begin{array}{lc}\begin{array}{c}\text { Vitamin added in the same } \quad \begin{array}{c}\text { Dry weight of } \\ \text { amount as in } A S P \text { a }\end{array} \\ \text { algae from } 6 \text { flasks } \\ (\mathrm{mg})\end{array} \\ \text { No addition } & 2 \cdot 0 \\ \text { All vitamins } & 23 \cdot 6 \\ \mathrm{~B}_{12} \text {. } & 22 \cdot 6 \\ \mathrm{~B}_{12} \text {, riboflavin, folic acid and } & 26 \cdot 6 \\ \text { pyridoxamine } & 30 \cdot 8 \\ \mathrm{~B}_{12} \text { and ribofiavin } & 28 \cdot 0 \\ \mathrm{~B}_{12} \text { and folic acid } & 26 \cdot 4\end{array}$

Table 2. GRowth of Polysiphonia urceolata with Different Natmrally OCOURRING $\mathrm{B}_{12}$ ANALOQUES. INCUBATION TIME, 30 DAYS. INOCULA STARVED FOR 26 DAYS

\begin{tabular}{|c|c|c|}
\hline $\mathrm{B}_{12} \underset{(1 \mu \mathrm{g} / 1 .)}{\operatorname{analogues}}$ & Base of nucleotide & $\begin{array}{l}\text { Dry weight of } \\
\text { algae from } 6 \\
\text { flasks (mg) }\end{array}$ \\
\hline $\begin{array}{l}\text { No addition } \\
\text { Cyanocobalamin }\left(=\mathbf{B}_{12}\right) \\
\text { Factor III } \\
\text { Factor Is }=\text { Factor } B\end{array}$ & $\begin{array}{l}\text { 5-6-dimethylbenzimidazole } \\
\text { 5-hydroxy benzimidazole }\end{array}$ & $\begin{array}{l}1 \cdot 8 * \\
24 \cdot 0 \\
20 \cdot 4\end{array}$ \\
\hline $\begin{array}{l}\text { pactor } B \\
\text { Pseudovitamin } B_{18} \\
\text { Factor } A \\
\text { Factor } X_{3} \\
\text { Factor } Z_{1}\end{array}$ & $\begin{array}{l}\text { None } \\
\text { None } \\
\text { Adenine } \\
\text { 2-methyladenine } \\
\text { None } \\
\text { None }\end{array}$ & $\begin{array}{l}11 \cdot 0 \\
5 \cdot 0 \\
8 \cdot 8 \\
4 \cdot 8 \\
13 \cdot 4 \\
16 \cdot 6\end{array}$ \\
\hline
\end{tabular}

Different, naturally occurring $B_{12}$ analogues were also tested (Table 2). During the first part of the experiment the alga grew with all additions. The best growth was obtained with cyanocobalamin and Factor III, but Poly. siphonia did not seem to 'prefer' Factor III to vitamin $\mathrm{B}_{12}$ as does Goniotrichum ${ }^{7}$. Another difference in the utilization of the different analogues could also be observed. Goniotrichum is unable to use Factor $B$ or pseudovitamin $\mathrm{B}_{12}$, whereas Factor $A$ gives as good growth as cyanocobalamin. In the series where these three factors were added, growth ceased after some days, and at the end of the experiment the algae were dead. This might indicate that factors with another base than benzimidazole in the nucleotide, or with no nucleotide at all, could be used only for some metabolic purposes.

Institute of Physiological Botany,

LISBETH FrIES

"Giraud, G. (personal communication).

S Fries, L., Nature, 183, 558 (1959).

- Fries, L., Experientia, 17, 75 (1961).

sries, L., Physiol. Plantar., 16, 695 (1963).

- Fries, L. (unpublished results)

'Fries, L., Physiol. Plantar., 18, 284 (1960). 